\title{
Representative Democracy in Australian Local Government
}

\section{Colin Hearfield and Brian Dollery}

University of New England, Australia
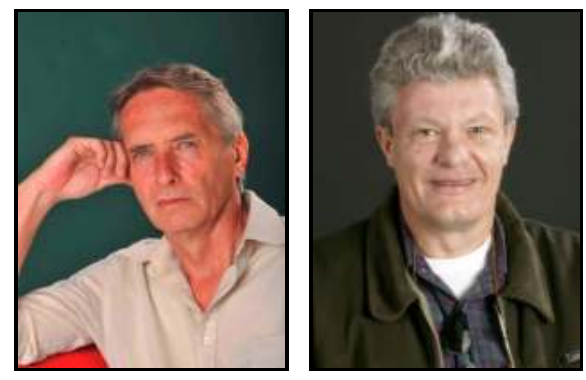

\begin{abstract}
In an assessment of representative democracy in Australian local government, this paper considers long-run changes in forms of political representation, methods of vote counting, franchise arrangements, numbers of local government bodies and elected representatives, as well as the thorny question of constitutional recognition. This discussion is set against the background of ongoing tensions between the drive for economic efficiency and the maintenance of political legitimacy, along with more deep-seated divisions emerging from the legal relationship between local and state governments and the resultant problems inherent in local government autonomy versus state intervention.
\end{abstract}

Key words: Representative democracy, vote counting methods, franchise criteria, constitutional recognition, councillors.

\section{Introduction}

The question of representative democracy in Australian local government has been overshadowed by the debate over the major micro-economic and managerial reforms carried out during the 1990s (Kiss 2003). These reforms were designed primarily to ensure local councils better fulfilled one of the principal roles of local government, namely the efficient delivery of services to local communities 
(Dollery et al. 2006). However, the second principal role of local government is to provide a forum for the practical expression of democratic values, in particular the representation of community interests both locally and, when appropriate, in wider regional contexts. Thus the reforms were also intended, at least ostensibly, to shift a previously widespread community perception of local councils as simply managers of local services and local infrastructure to one where this second principal role, as democratically representative bodies, gained in significance (Wensing 1997:37; Galligan 1998:205). While the micro-economic and managerial aspects of this structural reform process may have seen improved efficiencies (Dollery et al. 2008; Sorensen et al. 2007), there nonetheless remains palpable disquiet over what is perceived as the ongoing failure, or even a diminished capacity, on the part of local government to represent and respond to the needs expressed by local communities (May 2003:5). Kiss (2003:104) has argued that the representative legitimacy of local government has been "weakened instead of strengthened" by these reforms. In a slightly less critical vein, Aulich (1999:19) claimed that the dual roles of local government:

... are often in tension: for instance, in relation to the controversial question of municipal amalgamations, the argument for larger local government units is usually based on the existence of economies of scale in service delivery. The opponents of amalgamations generally claim that there are diseconomies of scale in relation to the democratic values of representativeness, with large municipal units less responsive to community needs and aspirations than smaller ones.

If, as Aulich indicates, attempts to realise economic efficiencies have in themselves hindered representative democracy, and if representative democracy remains the bedrock of political liberty, then the autonomy of local government, and thereby the freedom of the community represented, appears under siege.

In addition to these contemporary Australian concerns, the ongoing question of whether local government should be fully self-governing or subject to the sovereignty of the state has haunted the political theory of local government since its inception. As Wickwar (1970:1-2) puts it:

These antithetical positions run through the whole evolution of modern local government theory. They may be traced back to Western Europe's middle ages, when a tradition evolved of local liberties being in practice self-achieved, but ... this tradition was soon overshadowed by a legal doctrine of local bodies being incorporated by the sovereign. They may also be traced back to the emergence of the early modern state, when a new classical political theory hesitated between thinking of local bodies as quasi-sovereign constituents of the state or as subordinate intermediary bodies between the sovereign and his subjects.

During the late eighteenth century, the French administrator Turgot developed a plan dividing France into four geographic levels of municipality: the village, the region, the province and the entire nation. Those owning property would elect a village council to administer the allocation of tax revenues for local public works improvements, which would in turn elect a representative to the next level of municipal government. With the historical shift occurring during that time from 
aristocratic, monarchic to bourgeois, democratic forms of government, Turgot's plan soon became highly influential across Europe as well as in the United States and Britain. Under Napoleon's influence, however, the elected local representative was replaced with a centrally appointed administrator. Yet this approach was again generally reversed during the 1830s and 1840s. While Bentham in Britain emphasized the democratic principle of both central and local governments being responsible to the people, J.S. Mill argued that nonetheless local government should be open to investigation and advice from central government agencies. At the turn of the twentieth century, and contrary to the utilitarian centralism of Mill, a group of British Fabian socialists, including Sidney and Beatrice Webb, set out five principles for local government. As reported by Wickwar (1970:54-5), the fifth of those principles holds that:

[1] ocal government thus constituted and freed from judicial, statutory, and sublegislative restraints should enjoy as large a measure of freedom and dignity as possible. Even as it was, initiative and enterprise came as often from local as from central government. The principal historic units ought to be recognized as being true general-purpose authorities, exempt from the ultra vires doctrine applied to them by the law courts since the mid-nineteenth century ... In particular they should be free to furnish their public with any service that they could afford, by way of self-financing 'municipal socialism' and the provision of all manner of free educational, cultural, and health facilities. The new invention of grants-in-aid could contribute to municipal liberty insofar as they were given on a 'block' instead of a 'specific' basis.

In light of these historically-entwined perspectives on local government autonomy and state intervention, we turn our attention to a discussion of different forms of local representation and their close relation to different methods of vote counting. We then consider trends in the form of representation and vote counting methods in the context of Australian local government, before examining historical shifts in the franchise. A further factor shaping the representative character of Australian local government concerns a declining trend in the number of Australian local government bodies and increasing representative: population ratios. In a final section we consider the current lack of federal constitutional recognition of Australian local government and its implications for representative democracy.

\section{Forms of Representation and Vote counting Methods}

The case for a direct, participatory model of democracy, similar to that practiced by the ancient Greeks, was strongly advocated by the Swiss philosopher, J.J. Rousseau, during the mid-eighteenth century. However, with much larger expanses of territory and population now at stake than the old Athenian city-state or Rousseau's Geneva, the model of representative democracy, first practiced in the United States at the end of the eighteenth century, has generally been accepted as that most suitable for preserving the democratic principle of political equality. The English-born Thomas Paine (1969:202), in support of the American model of representative democracy, observed that "[b]y ingrafting representation upon democracy, we arrive at a system of government capable of embracing and confederating all the various interests and every extent of territory and population." 
Further prominent advocates of representative democracy at this time included the American James Maddison and the Englishman Edmund Burke. Both argued for what has become known as the trusteeship or corporate form of representation; a form which also implicates high levels of education in elected representatives. Maddison claimed that with large voting constituencies there was a greater chance those with talents and education would be elected (Phillips 2003:20). Burke maintained that elected representatives should be entrusted to make informed, independent judgments in the best interests of their constituents (Sawer 2003:39). In other words, freely-elected representatives should have the requisite knowledge and character to make such judgments, and, by virtue of election, are authorised to formulate policy and establish strategic directions on behalf of the social collective.

In defending this corporate, trusteeship form of representation, where the governing body is likened to a company board of directors, Burke and Maddison were also attempting to ensure that those elected would not simply be mouthpieces for particular interest groups or local parochial concerns. Yet those defending this phonographic or 'interest' form of representation, also known as populism, generally stand opposed to what they consider the educational elitism inherent in the idea of corporate trusteeship. They place great value on personal contact with the elected representative and the direct accountability of a member of parliament to those s/he represents rather than to any political party with which the representative may be aligned.

A third form of representation, known as the mirror form, was later advocated by J.S. Mill in the second half of the nineteenth century. Mill argued that the electoral system should make it possible for minority interests and opinions to be represented or mirrored on a proportional basis according to their numbers within an electorate. In common with Maddison and Burke, Mill's intention was to encourage a 'politics of ideas', where those with high intellectual capacities and independent modes of thinking would become elected representatives (Phillips 2003:21). Parliament, in Mill's view, should be a vigorous debating forum with various competing ideas. This is evident in Mill's opposition to proportional representation on the basis of social occupation, whereby parliament would more likely consist of so-called uneducated representatives drawn from the working classes. While Mill in no way denied that working class interests may be represented, his concomitant defence of property ownership as a key franchise criterion considerably reduced the possibility of such representation. Nevertheless, with the introduction of universal adult suffrage in Australia during the 1890s, the political representatives of the working classes became delegates whose views were to mirror party policy, which in turn reflected the interests of workers.

These forms of electoral representation are shaped to some degree by the particular method of vote counting used to determine successful candidates. As Burdess and O'Toole (2004:68) indicate, the two major means employed for this purpose are the majority and proportional methods. The former is a first-past-the-post, simple 
majority, or if preferences are to be nominated, an absolute majority mode of selection. Since the majority method, with or without preferences, is generally applied when only a single successful candidate is possible, it often produces an 'interest' form of representation. This has been the case particularly in local government elections where the ratio of population to elected representatives, especially in rural and regional areas, is relatively low.

In the case of multi-member electorates, however, a proportional method of vote counting is more common. This method depends on a certain quota of votes being reached: a quota being calculated according to the ratio of possible votes to available positions, and where the votes of eliminated candidates are transferred, through preferences, to those remaining in the count. This method gives rise to a mirror form of representation, since it has the capacity to reflect or register a variety of different political viewpoints within electoral divisions that are more densely populated or perhaps more geographically extensive. Table 1 provides a tabulated summary of the relations between vote counting methods and the forms of representation to which they generally give rise.

Burdess and O'Toole (2004) illustrate the manner in which local government in the state of Victoria has, through its voting methods, passed from a long history of interest representation to a period of corporate representation during the 1990s, and more recently to a mirror or proportional form of representation. They argue that:

A corporate view of representation is not dependent on one system [of vote counting] or the other but the type of system can skew representation in two significant ways. On the one hand, proportional systems may lead to unstable coalitions of minor groups who are often unable to agree on substantive issues. On the other hand, majority systems may skew the corporate representation towards limited interests in the community. (Burdess and O'Toole 2004:69)

Burdess and O'Toole also suggest (2004:75), as does Balmer (1982:12), that all three forms of representation may be embodied in the one elected representative and that, depending on a particular issue and its circumstances, a greater weighting may be attributed to the one or another. 
Table 1: Vote counting and Representation in Australian Local Government.

\begin{tabular}{|c|c|c|c|}
\hline & Majority & $\begin{array}{c}\text { Majority } \\
\text { Preferential }\end{array}$ & Proportional \\
\hline $\begin{array}{l}\text { Method of Vote } \\
\text { Counting }\end{array}$ & $\begin{array}{l}\text { Simple majority or } \\
\text { first-past-the-post } \\
\text { with no preferences } \\
\text { counted }\end{array}$ & $\begin{array}{l}\text { Absolute majority } \\
\text { with preferences } \\
\text { counted }\end{array}$ & $\begin{array}{l}\text { Quota of necessary } \\
\text { votes calculated } \\
\text { according to ratio of } \\
\text { possible votes to } \\
\text { available positions and } \\
\text { where votes of } \\
\text { eliminated candidates } \\
\text { are transferred, through } \\
\text { preferences, to those } \\
\text { remaining }\end{array}$ \\
\hline $\begin{array}{l}\text { States and } \\
\text { Territory }\end{array}$ & $\begin{array}{l}\text { Queensland, } \\
\text { Western Australia }\end{array}$ & $\begin{array}{l}\text { Northern Territory. } \\
\text { New South Wales } \\
\text { and Victoria when } \\
\text { only one or two } \\
\text { positions are to be } \\
\text { decided. } \\
\text { Queensland when } \\
\text { only one position is } \\
\text { to be decided. }\end{array}$ & $\begin{array}{l}\text { New South Wales, } \\
\text { Victoria, } \\
\text { South Australia, } \\
\text { Tasmania }\end{array}$ \\
\hline Application & $\begin{array}{l}\text { Both single and } \\
\text { multi-member } \\
\text { electorates }\end{array}$ & $\begin{array}{l}\text { Both single and } \\
\text { multi-member } \\
\text { electorates }\end{array}$ & $\begin{array}{l}\text { Multi-member } \\
\text { electorates }\end{array}$ \\
\hline $\begin{array}{l}\text { Form of } \\
\text { Representation }\end{array}$ & $\begin{array}{l}\text { Often produces a } \\
\text { 'phonographic' or } \\
\text { 'interest' form of } \\
\text { representation, also } \\
\text { known as populism }\end{array}$ & $\begin{array}{l}\text { Less prone to } \\
\text { populism since } \\
\text { preferential votes } \\
\text { are counted }\end{array}$ & $\begin{array}{l}\text { Generally gives rise to a } \\
\text { 'mirror' form of } \\
\text { representation where } \\
\text { the views of different } \\
\text { social groups are } \\
\text { proportionally reflected }\end{array}$ \\
\hline
\end{tabular}

\section{Trends in Vote counting Methods and Forms of Representation}

No definitive answer to the question of which form of representation is most democratic appears possible. However, in recent years a general trend towards the proportional method of vote counting is evident. The Association for Good Government carried out a study of the 1971 New South Wales local government elections to determine whether those council areas using a majority-preferential (MP) method of vote counting achieved a better or worse representative outcome than where proportional representation (PR) had been employed. As cited in a 1981 ACIR discussion paper (No.5:16), the key finding of the Association was that:

In every aspect of performance, examined in the survey, PR is superior to MP, generally by a very significant amount ... In general, ... the results of the survey show that ... proportional representation (PR) consistently gives results that are far more satisfactory to the voters and far more just to the candidates than those with the majority-preferential method (MP).

Majority-preferential voting in multi-member electorates can lead to candidates with a small primary vote nonetheless being elected on second and third preferences, although, as Hughes and Costar (2006:69) indicate, this is usually rare. Burdess and O'Toole (2004:74-5) outline the support given to the proportional 
method in Victoria by Labor Party ministers for local government in the late 1980s and again in 2002. They further indicate that the National Party has in recent years also lent support to the proportional or mirror form of representation, since some rural voters were said to be disenfranchised due to the overwhelming success of candidates from major regional centres in their electorate. Criticism of the proportional method is generally couched in terms of increased administrative complexities and opening the door to party political groupings in local government. Yet as the ACIR paper (1981:17) argued, candidates need to be aligned with particular or associated groups in their community, since without such support they stand little chance of election.

While each Australian state has made changes to its method of local government vote counting over the past century, four now use the proportional method for determining elected representatives in multi-member electorates. Two of these, Victoria and New South Wales, revert to the majority preferential method when only one or two positions are to be decided. South Australia and Tasmania, which once used the first-past-the-post and majority-preferential methods respectively, now employ the proportional method exclusively. Queensland and Western Australia use the simple majority or first-past-the-post method; however Queensland turns to majority- preferential voting when only one vacancy is to be decided. In the Northern Territory majority preferential voting is the norm (DOTARS 2006:12-13). Of the four states that employ the proportional method of vote counting and so appear to favour the mirror form of representation, only Tasmania has fully abolished the otherwise prevalent division of local government areas (electorates) into wards or ridings. In South Australia, according to figures from 2002, 85\% of local government electorates still maintain such divisions. Victoria is recorded as having $81 \%$ of local electorates divided this way, and New South Wales 45\% (Burdess and O'Toole 2004:68). Because any local government area may have a variety of combinations of single and multi-member wards or ridings, it remains difficult to gauge more precisely the overall extent of proportional representation in the three states that also use the majority-preferential method. However, data from Victoria in 2002 (Burdess and O'Toole 2004:72), indicated that over half the number of local council bodies had single member wards.

The move to 'whole-of-council' elections in certain states would also appear to strengthen the proportional, mirror form of representation. While ACIR (1981:13) indicated over twenty years ago that New South Wales, Queensland and the Northern Territory then held whole-of-council elections every three years, three of the other states were still committed to annual elections at which one-third of representatives would retire or stand for re-election each year after their three-year term. In South Australia, half the representatives relinquished their post annually after a two-year term. The 2004 Local Government National Report (DOTARS 2004:8) indicates that New South Wales had moved to a four-year cycle, Queensland remained unchanged on a three-year cycle, while Victoria and South Australia had moved to whole-of-council elections every three years. Western 
Australia and Tasmania now held a half council election every two years, while in the Northern Territory elections could vary between one and four years. Two years later, in the 2006 Local Government National Report (DOTARS 2006:12-13), four of the six states as well as the Northern Territory are reported as holding whole-ofcouncil elections every four years. Western Australia and Tasmania remained unchanged with half-council elections every two years. The shift to whole-ofcouncil elections every four years in Victoria and South Australia counters to some degree the interest form of representation otherwise prevalent in a ward system, where generally only one representative could be elected at any one time. For what is often at stake in that situation is not so much the exercise of good government by council as a whole, but simply the social standing and personal demeanor of individual candidates.

\section{Historical Shifts in the Local Government Franchise}

The franchise criteria evident at the time of federation, namely being a British subject of at least 21 years of age and being an owner of property, have been gradually modified during the course of the twentieth century. The age requirement for all tiers of government was reduced to 18 years across all states and territories during the early 1970s. At roughly the same time Victoria and South Australia both extended the local government franchise entitlement to include non-British subjects resident in the state. Western Australia followed suit with the proviso that nonBritish residents be nonetheless owners of property. The other three states, along with the Northern Territory, maintained being a British subject as a factor in determining any right to vote. Since 1984, however, being a British subject translates (except for those on a British or Commonwealth of Australia electoral roll prior to that year) as being on an Australian state or territory electoral roll; in other words, as being or having become an Australian citizen.

Property ownership as a criterion of franchise has a history stretching back to the pre-emergent condition of local governing bodies as road boards, which levied taxes on landholders for the construction and maintenance of local roads. With their transition to local governing bodies, taxes were extended to cover the provision of further services such as sewerage and waste disposal. Only genuine stakeholders in a local community, it was argued, namely those who paid such taxes or rates according to the value of their property or properties, should be entitled to vote and so have their interests represented in local council forums. This property-based franchise criterion also included those occupiers of land who directly paid rates, and the nominees of companies or corporations present in the electorate.

In most States the maximum number of votes able to be exercised by an elector in any one capacity was twelve. However any property-owner who was registered as the nominee of a company or as a ratepaying lessee could also cast votes in these capacities. Further, where the local authority was subdivided into wards and property was held in a number of wards, then voting rights were extended to each ward (ACIR 1981:5). 
The right to multiple votes based on the total value of property owned was first removed in New South Wales in 1906 (Power et al. 1981:31). Nevertheless, if properties were owned in more than one ward or riding within a local government area then the owner was still entitled to one vote in each of those wards. Also, additional votes could be cast if a property owner was also named as a corporate nominee. This modified form of plural voting was adopted in Western Australia in 1960, Victoria in 1968, South Australia in 1976, and Tasmania in 1978 (Power et al. 1981:31, 664, 724). Today, plural voting persists in Victoria and to a lesser extent Tasmania. New Local Government Acts passed during the 1990s by the New South Wales, South Australian and Western Australian governments retained a property franchise but applied the principle of one vote per voter across the entirety of any one local government area (Kiss 2003:113).

Queensland, however, abolished property ownership altogether as a franchise criterion and replaced it with that of residency and state electoral enrolment as early as 1920 (DOTARS 2006:13). Similarly in the Northern Territory, residency and territorial electoral enrolment are the sole criteria of franchise. Residency as a criterion of franchise was subsequently introduced in New South Wales in 1941, and while the other four States eventually followed, this did not occur in South Australia until as late as 1976 (Power et al. 1981:30-31), and in Victoria until 1982 (Kiss 2003:113). From an economic perspective, a key argument supporting residency as a criterion of franchise is that any rent paid to a property owner in return for lodgings effectively includes a proportion attributable to rates. A further argument is that the general-purpose grants allocated to local government by the Commonwealth are derived from personal income tax paid by all working residents.

While residency, age and citizenship have now become the dominant criteria of franchise in local government elections, property ownership remains a criterion in all States bar Queensland. In Western Australia and New South Wales, any nonresident property owner or occupier must nevertheless also meet the age and citizenship criteria. In Tasmania a voter satisfying these conditions may exercise the right to a proxy vote on behalf of a non-resident owner or occupier.

Overall, there was thus a marked decrease in the voting power of property owners during the second half of the twentieth century, and over the same period there was an increase in the number of eligible voters made possible through the introduction of the citizenship and residency criteria now applied in every state and the Northern Territory

\section{Declining Numbers of Local Government Bodies and Councillors ${ }^{1}$}

\footnotetext{
${ }^{1}$ The term 'alderman' was previously used for elected representatives of some city and municipal councils. We also note that our focus in this paper concerns representative democracy generally and so does not engage in any specific consideration of women or indigenous representatives.

Nevertheless it is evident over the last two decades that there has been a marked increase in the numbers of both.
} 
During the late nineteenth century, prior to federation, local government bodies were established through both the voluntary petition of resident stakeholder groups to their respective state governments, and mandatory decree. Soon after federation, in the very early twentieth century, five of the six states, with the exception of South Australia, had introduced exclusive mandatory requirements. At this time, the number of local government bodies had reached a zenith. Since then, due to ongoing boundary alterations and amalgamations promoted by state and territory governments, numbers of councils have generally declined. In New South Wales, Victoria and South Australia this decline has been in the order of $50 \%$ or more, while in Tasmania it is close to $40 \%$. Most recently, Queensland and the Northern Territory have undergone major reforms that have reduced the number of local governments by around $50 \%$ and $75 \%$ respectively. The changes in the Northern Territory, involving the amalgamation of small Indigenous community councils into new 'shires' covering vast areas of largely unpopulated land, could fairly be described as the most radical structural reform in Australian local government history. In Western Australia, by contrast, the number of local governing bodies has remained relatively steady since the time of federation with only a slight drop in numbers.

Table 2: Number of Local Councils in Australia 1910-2008.

\begin{tabular}{|c|c|c|c|c|c|c|}
\hline & $\mathbf{1 9 1 0}$ & $\mathbf{1 9 6 7}$ & $\mathbf{1 9 8 2}$ & $\mathbf{1 9 9 0}$ & $\mathbf{1 9 9 5}$ & $\mathbf{2 0 0 8}$ \\
\hline NSW & 324 & 224 & 175 & 176 & 177 & 152 \\
VIC & 206 & 210 & 211 & 210 & 184 & 79 \\
QLD & 164 & 131 & 134 & 134 & 125 & 73 \\
SA & 175 & 142 & 127 & $122^{*}$ & 119 & 68 \\
WA & 147 & 144 & 138 & 138 & 144 & 142 \\
TAS & 51 & 49 & 49 & 46 & 29 & 29 \\
NT & 0 & 1 & 6 & 22 & 63 & 16 \\
\hline
\end{tabular}

* Figure for 1991

Sources: Chapman (1997:4), May (2003:83), state local government department websites

This decline in the number of local government bodies has been accompanied by a corresponding reduction in the number of councillors. In Tasmania, South Australia and Victoria, the number of elected representatives has dropped by $37 \%$, $31 \%$ and $73 \%$ respectively - that is, from 460 to 288 , from 1100 to 760 , and from 2196 to 589 (Kiss 2003:109). A further contributing factor in this decline, albeit with lesser impact, has been the sharp fall in the maximum limit of councillors for each council in all states except Queensland since the late 1970s. For 1981, Power et al. (1981:30) record limits for cities in New South Wales and South Australia of around 20 elected representatives, 15 in Tasmania, and 11 in Queensland. Without no limits for cities in Victoria and Western Australia, Melbourne City Council is then reported as having 33 councillors, while the councils of Perth and Fremantle comprised 28 and 19 councillors respectively. However, according to the 2006 Local Government National Report (DOTARS 2006:12), the maximum limit in New South Wales and Western Australia had been reduced to 15, and in Victoria 12, while the other states had no specified limit. Nevertheless, with the exception of Brisbane City Council, which currently consists of 27 councillors, all the other 
capital city councils across the country currently have no more than twelve and in some instances only nine representatives. For smaller municipal and shire councils it would appear that the maximum limit has not varied significantly, except in Victoria where it has dropped from 18 to 12 . Furthermore, over the past 35 years, the minimum number of councillors for all categories of councils has fallen from six to five in most states.

Thus the overall number of local government representatives across the country is far lower than in previous decades. More significantly, and in view of national population growth, this indicates that each elected member now represents a much larger number of voters than ever before. That varies considerably from state to state with those more heavily populated having a far greater ratio of population per elected representative. Figures again taken from the 2006 Local Government National Report (DOTARS 2006:14) show that in Victoria, which has experienced the greatest fall in the number of local government representatives, this ratio recently stood at 1:8053. In New South Wales, where the population is almost 40 per cent higher, but where there has been a less dramatic drop in the number of councillors, the ratio was 1:4432. For Queensland (before the recent halving of the number of councils), South Australia and Tasmania, these ratios came in at 1:3079, 1:2046, and 1:1710 respectively. In Western Australia, with only a very slight decline in the numbers of councils and representatives, the ratio stood at 1:1475. It is also evident, in view of the still relatively large number of small municipal and shire councils in non-metropolitan areas, and the recent decline in the number of councillors in many larger urban councils, that the more densely populated metropolitan areas have a significantly larger number of people being represented by each elected representative than in rural and regional Australia.

The question which emerges here is: does this declining trend in the numbers of local government bodies and councillors actually decreases the representative and thereby democratic character of local government? An immediate affirmative response, however, would seem far too simplistic. For with the franchise having now been extended to all resident adult citizens, and with the trend towards proportional, mirror representation, where different and various viewpoints have a better chance of being represented in local government, it may well be argued that the representative, democratic character of local government is in fact increasing. This is an issue requiring further investigation.

\section{Constitutional Recognition and Local Government Autonomy}

With ever-expanding strategic responsibilities over recent decades in the areas of economic, social and environmental planning, the significance of local councils in shaping the future well-being of their respective communities has been dramatically heightened. Not only has the managerial role of councils with regard to the efficient provision of services become more professionalised, but also councils have been actively encouraged to engage more fully with their community, to be more responsive to community needs, and so better fulfil their second major role of providing effective democratic representation. Certainly, since 
the extension of the franchise to all residents, local government has come to see itself as increasingly responsible for the whole community and not just property owners. This widening social responsibility is also substantiated on economic grounds; namely local government's expanded revenue base due to the provision of Commonwealth general-purpose grants derived in part from personal income tax (ACIR 1981:6). The significance of local councils as governing democratic bodies has also been recognized, at least to some extent, through the current emphasis on inter-government partnership arrangements with both state and Commonwealth governments. The major political manifestation of this partnership arrangement is the participation of the peak local government body, the Australian Local Government Association (ALGA), in the Council of Australian Governments (COAG).

The steps leading to this still informal recognition of local government as a third tier of government have been long and arduous. Perhaps the first sign of recognition came with the Whitlam government's 1974 referendum on whether the Commonwealth should have the right to provide direct grants to local councils. Despite overwhelming rejection, the referendum nonetheless brought increased attention to the role of local government. This is nowhere more evident than in the Fraser government's establishment in 1976 of the Advisory Council for Intergovernment Relations (ACIR). An indirect effect of the information and discussion papers thereafter published by ACIR was the formal recognition of local government in four state constitutions: Victoria and Western Australia in 1979, South Australia in 1980, and New South Wales in 1986 (Chapman 1997:6). However, while enhancing the status of local government in the four states, none of those constitutional amendments, achieved simply through an Act of parliament, guarantees local government any basic powers (ACIR 1985:9).

With this in mind, and despite potential challenges in the High Court over the interpretation of any reference to local government that might be inserted in the Commonwealth constitution, ACIR went on to recommend that recognition of local government be entrenched therein on the grounds that this would "explicitly draw attention to the complementary nature of the three spheres of government and implicitly point to their status as partners in the Australian governmental system" (1985:15). Just such a proposition was put to the Australian people in the referendum of 1988 , only to be soundly rebuffed. Indeed the 1987 Constitutional Commission had already made the point that such a proposal would institute a third sphere of government leading to counter-productive competition with the states (Chapman 1997:6). In view of previous displays of opportunistic behaviour on the part of all levels of government, Chapman similarly throws doubt on their capacity to engage in any genuine collaborative effort to achieve effective local policy outcomes. For this reason, he argues that "the rational allocation of responsibilities, optimistically espoused by the ACIR publications, is not really viable" (Chapman 1997:12). Nonetheless the failure to recognize the autonomy of local government in the Commonwealth constitution severely undermines its democratic legitimacy. 
Whilst the legislative reforms of the 1990s conferred some degree of 'general competence' power on local councils, that is, allowed councils a modicum of autonomy with respect to planning for and managing their local populace, their activities are still strictly controlled within the limits of state government legislation. Under these conditions, those elected to local government are often viewed as nothing more than the political and economic executors of policies emerging from their respective state governments. Moreover, local councils remain subject to the possibility of summary dismissal through ministerial fiat or a legislative act of state parliament, which further reinforces the public perception of local government as nothing more than a subsidiary, administrative arm of state government. This perception is largely borne out by the relatively small numbers voting at local government elections and is a significant factor undermining the democratic legitimacy of local government. While voting is compulsory in New South Wales, Queensland and more recently Victoria, available data (ACIR 1981:9) suggest that this still only results in somewhere between 65 and $85 \%$ of all eligible voters turning out to vote. In those other states where voting remains voluntary, the corresponding numbers range from as low as 5 to $40 \%$ (ACIR 1981:9). With higher numbers of voters in those states where voting is compulsory, there is less risk of minority interest groups gaining control of a council and some confidence that the results reflect the views of the electorate. Formal recognition of local government autonomy in the Commonwealth constitution could go a long way to changing the current public perception of local government and might thus encourage greater electoral participation.

\section{Concluding Remarks}

The trend away from a property-based franchise and plural voting to one based on residency and one person-one vote has enhanced the representative legitimacy of local government. In addition, shifts towards a proportional method of vote counting in whole-of-council elections have brought about greater representation of different community views. Further, the division of local government areas into wards or ridings may ensure that different geographical areas are well represented, although this system may tend to favour the phonographic or direct interest form of representation with its inherent parochialism, especially when only one candidate is to be elected and the majority method of vote counting is employed. On the other hand, there has been a marked decline in the number of councils and councillors in many states due to local government reforms initiated by state governments and ongoing boundary adjustments. This has resulted in increased representative : population ratios, particularly in densely populated metropolitan areas, and may have decreased the representative, democratic capacity of local governing bodies, although the proportional, mirror form of representation may obviate this problem to some degree.

Alongside these ongoing difficulties in determining the best form of representative democracy for Australian local government, a serious flaw in current arrangements is the lack of Commonwealth constitutional recognition of local government as a third and autonomous sphere of government. As May (2003:85) puts it in reference 
to an observation made by Stephen Soul (2000): "[w]ithout constitutional backing, Australian local government institutions cannot be truly regarded as legitimate democratic entities."

\section{References}

ACIR [Advisory Council for Inter-government Relations], 1981. Local Government Franchise, Voting and Electoral Arrangements. Discussion Paper 5, Hobart. --(1985) Implications of Constitutional Recognition for Australian Local Government. Report 8, Hobart.

Aulich, C. 1999. 'From Convergence to Divergence: Reforming Australian Local Government'. Australian Journal of Public Administration, 58(2), pp. 12-23.

Balmer, C. 1982. The Role of Local Government Councillors. ACIR Discussion Paper 11, Hobart.

Burdess, N. and K. O'Toole, 2004. 'Elections and representation in local government: A Victorian case study', Australian Journal of Public Administration, vol. 63(2), pp. 6676.

Byrnes, J.D. and B.E. Dollery, 2002. 'Local government failure in Australia: An empirical analysis of New South Wales', Australian Journal of Public Administration, vol. 61(3), pp. 54-64.

Chapman, R. 1997. 'The Role of Local Government in Australia', in R. Chapman, M. Haward and B. Ryan (eds), Local Government Restructuring in Australasia, University of Tasmania: The Centre for Public Management and Policy, Hobart.

Dollery, B., Marshall, N. and A. Worthington (eds), 2003. Reshaping Australian Local Government, University of New South Wales Press, Sydney.

Dollery, B.E., Crase, L. and A. Johnson, 2006. Australian Local Government Economics, University of New South Wales Press, Sydney.

Dollery, B.E., Byrnes, J.D. and L. Crase, 2008. 'A note on structural reform in Australian local government', Australian Journal of Political Science (forthcoming).

DOTARS [Department of Transport and Regional Services], 2004. Local Government National Report 2002-03. National Office of Local Government, Canberra. -- (2006) Local Government National Report 2004-05, National Office of Local Government, Canberra.

Galligan, B. 1998. 'Democracy and Local Government Change', in B. Galligan (ed.), Local Government Reform in Victoria, State Library of Victoria Press, Melbourne.

Hughes, C. and B. Costar, 2006. Limiting Democracy: The erosion of electoral rights in Australia, University of New South Wales Press, Sydney.

Kiss, R. 2003. 'Reasserting Local Democracy?', in B. Dollery, N. Marshall and A. Worthington (eds), Reshaping Australian Local Government, University of New South Wales Press, Sydney.

Local Government Association of the Northern Territory, <http://www.lgant.nt.gov.au/lgant/content/view/full/2053>.

Local Government Association of South Australia, $<$ http://www.lga.sa.gov.au/site/page.cfm?u=210>.

Local Government Association of Tasmania, <http://www.lgat.tas.gov.au/site/page.cfm?u=225>. 
May, P. 2003. 'Amalgamation and Virtual Local Government', in B. Dollery, N. Marshall and A. Worthington (eds), Reshaping Australian Local Government, University of New South Wales Press, Sydney.

Municipal Association of Victoria, 〈http://www.vlga.org.au/webpage/about/list-councils.chtml>.

New South Wales Local Government and Shires Association, <http://www.lgsa.org.au/www/html/134-council-websites.asp>.

Paine, T. 1969. The Rights of Man, Penguin, Harmondsworth, pp. 1791-1792.

Phillips, A. 2003. 'Representation Renewed', in M. Sawer and G. Zappala (eds), Speaking for the People: Representation in Australian Politics, University of Melbourne Press, Carlton South.

Power, J., Wettenhall, R. and J. Halligan (eds), 1981. Local Government Systems of Australia. ACIR Information Paper No.7. AGPS, Canberra.

Queensland Department of Local Government, Sport and Recreation, <http://www.lpg.qld.gov.au/applications/lgDirectory/Summary/>.

Sawer, M. 2003. 'Representing Trees, Acres, Voters and Non-voters: Concepts of Parliamentary Representation in Australia', in M. Sawer and G. Zappala (eds), Speaking for the People: representation in Australian Politics, University of Melbourne Press, Carleton South.

Sorensen, T., Marshall, N.A. and B.E. Dollery, 2007. 'Changing governance of Australian regional development: Systems and effectiveness', Space and Polity, 11(3), pp. 297315 .

Soul, S.C. 2000. Population Size and Economic and Political Performance of Local Government Jurisdictions. Ph.D. Thesis, Southern Cross University, Lismore.

Wensing, E. 1997. 'Systemic Reform or Administrative Update? Recent Legislative Changes in Local Government around Australia', in R. Chapman, M. Haward and B. Ryan (eds), Local Government Restructuring in Australasia, The Centre for Public Management and Policy, University of Tasmania, Hobart.

Western Australian Local Government Association, <http://www.walga.asn.au/about_lg/council_websites $>$.

Wickwar, W.H. 1970. The Political Theory of Local Government. University of South Carolina Press, Columbia. 